Archives of Agriculture and Environmental Science

\title{
Current status of bacterial contamination in some fish species of Bakkhali river Estuary, Bangladesh
}

\author{
Sharmin Jahan ${ }^{1}$, Md. Abu Sayed Jewel ${ }^{1 *}$ iD, Md. Ayenuddin Haque ${ }^{1}$, Jakia Hasan², Most. \\ Momtahena Mita ${ }^{1}$, Ambia Aktar ${ }^{1}$ and Md. Al-Amin ${ }^{1}$ \\ ${ }^{1}$ Department of Fisheries, Faculty of Agriculture, University of Rajshahi, BANGLADESH \\ ${ }^{2}$ Bangladesh Fisheries Research Institute (BFRI), Marine Fisheries \& Technology Station, Cox's Bazar, BANGLADESH \\ "Corresponding author's E-mail: jewelru75@yahoo.com
}

\section{ARTICLE HISTORY}

Received: 30 January 2019

Revised received: 26 February 2019

Accepted: 02 March 2019

\section{Keywords}

Bacterial pollution

Bakkhali River estuary

Fish organs

Pathogenic bacteria

\section{ABSTRACT}

The present study aims to investigate the isolation of human pathogenic bacteria (Escherichia coli, Salmonella spp. Shigella spp. and Vibrio spp.) and in gills, intestines, skin of fishes of Bakkhali River Estuary, Cox's Bazar. A total of 50 fish species (25 of Pomadasys hasta and 25 of Glossogobius giuris) were collected from two sampling stations namely Station-1 (Rumalia Chara) and Station-2 (Kusturi Ghat). Bacterial analyses were made by standard methods. Total heterotrophic bacterial load of the isolates was found to be lower than the recommended public health and standard. However, the highest pathogenic bacterial (E. coli, Salmonella spp. Shigella spp. and Vibrio spp.) count at Station-2 might be due to the contamination of municipal and domestic wastes and discharges from small industries that constitute the main pollution source of this estuarine river. Skin was found to be the most preferred organs for higher bacterial load compared to intestine and lower count was recorded in gills. Further research on the microbial quality assessment should be undertaken to prevent pollution of this river estuary.

(C)2019 Agriculture and Environmental Science Academy

Citation of this article: Jahan, S., Jewel, M.A.S., Haque, M.A., Hasan, J., Mita, M.M., Aktar, A. and Al-Amin, M. (2019). Current status of bacterial contamination in some fish species of Bakkhali river Estuary, Bangladesh. Archives of Agriculture and Environmental Science, 4 (1): 96-100, https://dx.doi.org/10.26832/24566632.2019.0401015

\section{INTRODUCTION}

Several researchers have reported the isolation of bacteria belonging to different genera from fish as an indicator of pollution study (Adewoye and Lateef, 2004; Hamed et al., 2013; Kolawole et al., 2011). Fish can harbor varieties of pathogens on or inside its body as they reside at the top of the food chain (Dahunsi et al., 2012). Fishes are extremely susceptible to bacterial contamination due to their soft body organs. Use of fish as a bioindicator of bacterial pollution can provide cumulative effect of different pollutant in the ecosystem (Santos et al., 2011). The presence of FC as E. coli serves as an indicator for the possible presence of other disease-causing pathogens (Rajkumar and Sharma, 2013). Currently, coliforms and E. coli are of great importance among bacterial indicators used in water quality definition and health risk (Giannoulis et al., 2005). Pathogens are a serious concern for managers of water resources, because excessive amounts of faecal bacteria in sewage and urban run-off have been known to indicate risk of pathogen-induced illnesses in humans. The pathogens that may occur in surface water as a result of fecal contamination vary depending on the source of the contamination. Human fecal pollution may cause the greatest health risk because humans act as reservoirs for human enteric bacteria such as Salmonella sp. and Shigella sp. (McLellan and Salmore, 2003). Thus, detection and an enumeration of indicator organisms are of primary importance for the monitoring of sanitary and microbiological quality of water (Gunnison, 1999).

The Bakkhali river estuary located at the south-eastern part of Bangladesh serves an important harbor in the economics of local fishery of Cox's Bazar district (Hena et al., 2007). It is enriched with about 490 species of fishes (Hossain, 1971) and 19 species of shrimps/prawn (Chowdhury and Sanaullah, 1991) 
that ensure sustainable livelihood of a large number of fishing households. This estuarine river also possesses an extensive environment for different aquatic organisms, which serves as feeding, breeding and nursery grounds for a variety of animals. It is highly productive in terms of nutrient input from different sources that promotes other living resources (Kamal and Khan, 2009). However, continuous environmental disturbance like sedimentation, urban runoff and pollution are badly affecting the ecosystem of this estuary (Hena et al., 2012). Bakkhali river is the main discharge point of the city waste of Cox's Bazar. Most of the indigenous effluents come from Cox's Bazar city and eventually flow into the Bakkhali river through a system of canals. As there are no potential industries in Cox's Bazar, municipal and domestic wastes and discharges from small industries constitute the main pollution source of this estuarine river. Waste discharge and chemical spills are mainly connected with boat repair industry that represents an additional source of pollutants to the water and sediments.

However, several studies have been conducted on pollution and other entities of Bakkhali river estuary (Siddique et al., 2012; Rashed-Un-Nabi et al., 2011; Hena et al., 2012). But information regarding bacterial pollution of this estuarine system is lacking. The present study was therefore designed to evaluate the bacterial load in different organs of fishes to evaluate the current pollution status of this estuarine river.

\section{MATERIALS AND METHODS}

\section{Collection of sample}

A total of 50 fish species (25 of and 25 of) were collected from two sampling stations namely Station-1 (Rumalia chara) and Station-2 (Kusturi Ghat) (Figure 1). A total of 50 fish species (25 of species 1 and 25 of species 2) were collected from the selected two sampling stations. Species-1 was Pomadasys hasta and Species-2 was Glossogobius giuris. Station-1 was characterized by less polluted areas and Station-2 was contaminated with anthropogenic and industrial activities where large amount of organic and inorganic wastes are being discharged. The fishes were collected from local fisherman in the morning. Gill nets of about $12.192 \mathrm{~m}$ long and $1.828 \mathrm{~m}$ wide with a cork line at the top rope and metal line with the ground rope made locally of nylon were used for fishing. The collected fishes were transported with sterilized plastic bucket to the laboratory.

\section{Preparation of samples}

In the laboratory, fish samples were washed with phosphate buffer saline and the various organs were separated with sterilized knife. Twenty (20) gram of each part (skin, gill and intestine) was homogenized separately in $250 \mathrm{~mL}$ of $0.1 \%(\mathrm{w} / \mathrm{v})$ PBS using vortex machine (Model iSwix VT) before serial dilution using the method of Odoli (2006). All the samples were collected in triplicates.

\section{Bacterial analysis}

Bacterial analysis was conducted in the microbiology laboratory of Bangladesh Fisheries Research Institute (BFRI), Marine Fisheries \& Technology Station, Cox's Bazar, Bangladesh. Spread plate method was carried out to count the bacterial density. $0.1 \mathrm{ml}$ of diluted samples was incubated in the petri-dish containing the culture media. Enumeration of Total heterotrophic bacteria (THB) was done on nutrient agar media (HiMedia) after incubating at $37^{\circ} \mathrm{C}$ for 18-24 h. MacConkey agar and EMB agar were used to the enumeration of Escherichia coli. Pink colonies that occur in MacConkey agar plate after the incubation period of $18-24 \mathrm{~h}$ at $37^{\circ} \mathrm{C}$ were recultured in EMB agar plate at $44-44.5^{\circ} \mathrm{C}$ for overnight. Colonies appearing as green metallic sheen in EMB agar were further subjected to biochemical test (iMVIC test) for the confirmation of the presence of E. coli. Vibrio spp., Salmonella spp. and Shigella spp. were enumerated using TCBS agar and SS agar plate (HiMedia) after incubation at $37^{\circ} \mathrm{C}$ for $18-24 \mathrm{~h}$. Yellow with opaque centers colonies were considered as Vibrio spp.; and colourless transparent and black centers colonies were considered as Salmonella spp. Colonies were counted on a digital colony counter as colony forming unit per gram (Cfu/g) of the sample.

\section{Statistical analysis}

The data were analyzed by the use of Statistical Package for Social Science (SPSS software Version 20.0). T-test was used to show the difference between the bacterial counting of two study sites at significance level of $p<0.05$.

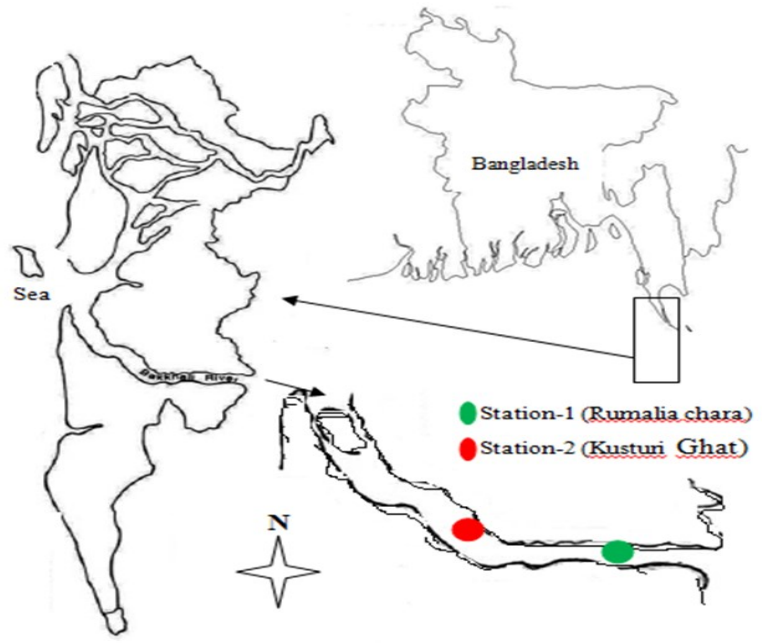

Figure 1. Sampling stations in Bakkhali river estuary. 


\section{RESULTS AND DISCUSSION}

\section{Mean bacterial count}

Mean bacterial count of fishes at two different sampling stations is shown in Table 1. Counting showed a significant difference in THB, E. coli, Vibrio spp., Salmonella spp. and Shigella spp. between the two study locations, whereas significantly higher bacterial count was found at Station- 2 in both of the two fish species. However, irregular pattern in bacterial count was observed between the fish species. The maximum microbiological limit for the THB, which separates the good quality products from bad quality, is $500000 \mathrm{cfu} / \mathrm{g}$ (ICMSF, 1986). The THB of the studied samples was below the maximum acceptable limit. Pathogenic bacteria i.e. E. coli, Salmonella spp., Shigella spp. and vibrio spp. isolated from the studied fish species were also beyond the limit of microbiological guidelines for foodborne pathogens as cited by Gilbert et al. (2000). Zambuchini et al. (2008) reported that the Enterobacteriaceae count is considered as the index of fish quality. Claucas et al. (1996) showed that when pathogens such as Salmonella spp., Shigella spp., Vibrio spp. present in food they are most likely to cause foodborne diseases. Therefore, monitoring of these microorganisms has been suggested as a measure of fish quality as well as environmental quality. According to Sichewo et al. (2014), the presence of coliforms in fish demonstrates the level of pollution of their environment because coliforms are not the normal bacterial flora in fish. The highest pathogenic bacterial count at Station-2 might be due to the poor sanitation system in that surrounding area where latrines directly connected with the river discharging of municipal and domestic wastes and industrial pollution. Runoff from vegetable and fish market which carry animal wastes was also a significant source of higher bacterial count in the Bakkhali river estuary.

\section{Bacterial counts in different organs}

Bacterial count in different organs of the fish species at the two studied sites is shown in Table 2. THB count was found highest at Station-2 in the skin of Species-1 (147333.33 $\pm 21361.96 \mathrm{cfu} / \mathrm{g}$ ) and the lowest in the gill of Species-2 $(1600.00 \pm 529.15 \mathrm{cfu} / \mathrm{g})$ at Station -1. Skin of Species-1 $(6260.00 \pm 1080.56 \mathrm{cfu} / \mathrm{g})$ was found vastly contaminated with E. coli at Station-2; however, Vibrio spp. count was the highest at the same Station in Species-2 $(1343.33 \pm 496.62$ $\mathrm{cfu} / \mathrm{g})$. Salmonella spp. and Shigella spp. count were observed higher at Station-2 in the skin of Species- $2(3346.67 \pm 423.36 \mathrm{cfu} / \mathrm{g}$ and $1536.67 \pm 272.27 \mathrm{cfu} / \mathrm{g}$, respectively). Similarly, Sujatha et al. (2011) isolated E. coli, Shigella spp. and Salmonella spp. from the gills, intestines and skin of Megalaspis cordyla and muscles of Priacanthus hamrur, whereas they reported higher bacterial count in the skin of the fishes. The higher bacterial count in the skin of fishes in both Station-1 and Station-2 might by due to the higher bacterial load in the water. However, in the present study, higher bacterial count in the fishes of Station-2 might be due to more polluted water of this Station. Similar observation was also made by Latha and Mohan (2013), where they reported that in polluted water fish showed higher load of microorganisms count in skin due to the pollution of water body. In the present study, the bacterial load was lower in gills of both the fish species compared to other organs. That might be due to the nature of the gills, where micro flora was unlikely unable to alter significantly the physical and chemical environment of the gill (Latha and Mohan, 2013). In the present study, the pollution nature of the water body was found to determine the bacterial load of intestine of the fishes. The growth promoting and inhabiting substances were found to decrease the bacterial count in the intestine compared to the skin of the studied fishes as similar to the findings of Austin (2002). Therefore, the present study has displayed that Station-2 was more contaminated representing a potential hazard to the health of local people.

Table 1. Mean bacterial count (cfu/g) of fishes.

\begin{tabular}{|c|c|c|c|c|}
\hline & Station-1 & Station-2 & t-value & P-value \\
\hline \multicolumn{5}{|l|}{ Species -1} \\
\hline THB & $3366.67 \pm 1830.30$ & $107066.67 \pm 42411.17$ & -7.329 & 0.000 \\
\hline E. coli & $255.56 \pm 88.19$ & $4217.78 \pm 1898.54$ & -6.254 & 0.000 \\
\hline Salmonell spp. & $211.11 \pm 105.41$ & $2537.78 \pm 1015.16$ & -6.839 & 0.000 \\
\hline Shigella spp. & $15.56 \pm 18.10$ & $847.78 \pm 604.89$ & -4.126 & 0.001 \\
\hline Vibrio spp. & $17.78 \pm 17.16$ & $883.33 \pm 581.98$ & -4.730 & 0.000 \\
\hline \multicolumn{5}{|l|}{ Species -2 } \\
\hline THB & $2766.67 \pm 1072.38$ & $61444.44 \pm 19626.46$ & -8.956 & 0.000 \\
\hline E. coli & $300.00 \pm 239.79$ & $3133.33 \pm 1268.52$ & -6.584 & 0.000 \\
\hline Salmonell spp. & $233.33 \pm 150.00$ & $2333.33 \pm 849.44$ & -4.460 & 0.000 \\
\hline Shigella spp. & $31.11 \pm 34.08$ & $1058.89 \pm 676.97$ & -4.549 & 0.000 \\
\hline Vibrio spp. & $13.33 \pm 12.25$ & $681.11 \pm 423.39$ & -7.304 & 0.000 \\
\hline
\end{tabular}


Table 2. Bacterial counts (cfu/g) in different organs of fishes.

\begin{tabular}{|c|c|c|c|c|}
\hline Bacteria & & Organs & Station 1 & Station 2 \\
\hline \multirow{7}{*}{ THB } & \multirow{3}{*}{ Species-1 } & Skin & $5300.00 \pm 953.94$ & $147333.33 \pm 21361.96$ \\
\hline & & Gill & $1466.67 \pm 642.91$ & $60033.33 \pm 10758.41$ \\
\hline & & Intestine & $3333.33 \pm 1026.32$ & $113833.33 \pm 28350.72$ \\
\hline & \multirow{3}{*}{ Species-2 } & Skin & $3133.33 \pm 901.85$ & $84366.67 \pm 7054.31$ \\
\hline & & Gill & $1600.00 \pm 529.15$ & $44166.67 \pm 11025.58$ \\
\hline & & Intestine & $3566.67 \pm 550.76$ & $55800.00 \pm 9260.13$ \\
\hline & \multirow{3}{*}{ Species-1 } & Skin & $266.67 \pm 57.74$ & $6260.00 \pm 1080.56$ \\
\hline \multirow{4}{*}{ E. Coli } & & Gill & $233.33 \pm 57.74$ & $2156.67 \pm 408.57$ \\
\hline & & Intestine & $266.67 \pm 152.75$ & $4236.67 \pm 674.19$ \\
\hline & \multirow{3}{*}{ Species-2 } & Skin & $366.67 \pm 305.51$ & $4346.67 \pm 699.45$ \\
\hline & & Gill & $133.33 \pm 57.74$ & $1696.67 \pm 207.93$ \\
\hline \multirow{8}{*}{ Salmonella spp. } & & Intestine & $400.00 \pm 264.58$ & $3356.67 \pm 724.59$ \\
\hline & \multirow{3}{*}{ Species-1 } & Skin & $200.00 \pm 100.00$ & $3260.00 \pm 1080.56$ \\
\hline & & Gill & $200.00 \pm 100.00$ & $1856.67 \pm 142.95$ \\
\hline & & Intestine & $233.33 \pm 152.75$ & $2496.67 \pm 1205.54$ \\
\hline & & Skin & $300.00 \pm 200.00$ & $3346.67 \pm 423.36$ \\
\hline & \multirow[t]{3}{*}{ Species-2 } & Gill & $133.33 \pm 57.74$ & $1656.67 \pm 231.59$ \\
\hline & & Intestine & $266.67 \pm 152.75$ & $1996.67 \pm 506.19$ \\
\hline & & Skin & $30.00 \pm 20.00$ & $1210.00 \pm 115.33$ \\
\hline \multirow{4}{*}{ Shigella spp. } & \multirow[t]{2}{*}{ Species-1 } & Gill & $0.00 \pm 0.00$ & $323.33 \pm 95.04$ \\
\hline & & Intestine & $16.67 \pm 15.28$ & $1010.00 \pm 890.17$ \\
\hline & \multirow{3}{*}{ Species-2 } & Skin & $53.33 \pm 51.32$ & $1536.67 \pm 272.27$ \\
\hline & & Gill & $26.67 \pm 25.17$ & $220.00 \pm 105.36$ \\
\hline \multirow{7}{*}{ Vibrio spp. } & & Intestine & $13.33 \pm 11.55$ & $1420.00 \pm 392.81$ \\
\hline & \multirow{3}{*}{ Species-1 } & Skin & $20.00 \pm 10.00$ & $893.33 \pm 65.06$ \\
\hline & & Gill & $3.33 \pm 5.77$ & $323.33 \pm 95.04$ \\
\hline & & Intestine & $16.67 \pm 15.28$ & $826.67 \pm 642.21$ \\
\hline & \multirow{3}{*}{ Species-2 } & Skin & $13.33 \pm 15.28$ & $1343.33 \pm 496.62$ \\
\hline & & Gill & $13.33 \pm 11.55$ & $220.00 \pm 105.36$ \\
\hline & & Intestine & $26.67 \pm 25.17$ & $1086.67 \pm 240.07$ \\
\hline
\end{tabular}

Conclusion

Presence of large amount of pathogenic bacteria i.e. E. coli, (4217.78 $\pm 1898.54 \mathrm{cfu} / \mathrm{g}$ in Species-1 at Station-2) Salmonella spp. (2537.78 $\pm 1015.16 \mathrm{cgu} / \mathrm{g}$ in Species-1 at Station-2), Shigella spp. $(1058.89 \pm 676.97 \mathrm{cgu} / \mathrm{g}$ in Species-2 at Station-2) and Vibrio spp. $(883.33 \pm 581.98$ in Species-1 at Station-2) in the two fish species collected from Bakkhali river estuary river of Cox's bazar indicated high levels of faecal contamination in the river due to heavy load of improper sewage dumping, municipal waste and industrial waste water. There may be a potential hazard of infection from food borne diseases to the residents from the encircling inhabitants from consuming the fish. Further research work should be conducted on overall pollution status of Pasur river estuary.

\section{ACKNOWLEDGEMENTS}

The authors wish to thank chief scientific officer, Bangladesh Fisheries Research Institute (BFRI), Marine Fisheries \& Technology Station, Cox's Bazar, Bangladesh for helping with the microbiological analysis. The work was financially supported by the University Grants Commission (1383-5/52/BIMOK/KRISHI-5/18-19).
Open Access: This is an open access article distributed under the terms of the Creative Commons Attribution 4.0 License, which permits unrestricted use, distribution, and reproduction in any medium, provided the original author(s) if the sources are credited.

\section{REFERENCES}

Adewoye, S.O. and Lateef, A. (2004). Assessment of the microbiological quality of Clarias gariepinus exposed to an industrial effluent in Nigeria. The Environmentalist, 24(4): 249254, https://doi.org/10.1007/s10669-005-1000-7

Austin, B. (2002). The Bacterial Microflora of Fish. Science World Journal, 2: 558-572, https://doi.org/10.1100/tsw.2002.137

Chowdhury, Z.A. and Sanaullah, M. (1991). A check list of the shrimps/ prawns of the Maheshkhali Channel, Cox's Bazar. Bangladesh Journal of Zoology, 19 (1): 147-150.

Claucas, I.J. and Ward, A.R. (1996). Post-harvest fisheries development: A guide to handling, preservation, processing and quality. Charthan, Maritime, Kent ME4 4TB, United Kingdom.

Dahunsi, S.O., Oranusi, S.U. and Ishola R.O. (2012). Differential bioaccumulation of heavy metals in selected biomarkers of 
Clarias gariepinus (Burchell, 1822) exposed to chemical additives effluent. Journal of Research in Environmental Science and Toxicology, 1(5):100-106, http://www.interesjournals.org/JREST

Giannoulis, N., Maipa, V., Konstantinou, I., Albanis, T. and Dimoliatis, I. (2005). Microbiological risk assessment of Agios Georgios source supplies in north western Greece based on faecal coliform determination and sanitary inspection survey. Chemosphere, 58: 1269-1276, https://doi.org/10.1016/j.chemosphere.2004.09.078

Gilbert, R.J., de Louvois, J. and Donovan, T. (2000). Guidelines for the microbiological quality of some ready-to-eat foods sampled at the point of sale. PHLS Advisory Committee for Food and Dairy Products. Communicable Disease and Public Health, 3(3):163-167, https://www.ncbi.nlm.nih.gov/pubmed/11014026.

Gunnison, D. (1999). Evaluating Microbial Pathogens in Reservoirs. Water Quality Technical Notes Collection. US Army Engineer Research and Development Center, USA.

Hamed, Y.A., Abdelmoneim, T.S., ElKiki, M.H., Hassan, M.A. and Berndtsson, R. (2013). Assessment of heavy metals pollution and microbial contamination in water, sediments and fish of Lake Manzala, Egypt. Life Science Journal, 10(1): 86-99.

Hena, A.M.K., Kohinoor, S.M.S., Siddique, M.A.M. Ismail, J., Idris, M.H. and Amin, S.M.N. (2012). Composition of macrobenthos in the Bakkhali Channel System, Cox's Bazar with notes on soil parameter. Pakistan Journal of Biological Sciences, $\quad 15 \quad$ (13): $\quad 641-646$, https://scialert.net/abstract/?doi=pjbs.2012.641.646

Hena, A.M.K., Short, F.T., Sharifuzzaman, S.M., Haque, M.N., Hasan, M., Rezowan, M. and Ali,M. (2007). Salt marsh and seagrass communities of Bakkhali estuary, Cox's Bazar, Bangladesh. Estuarine Coastal and Shelf Science, 75: 72-78, https://doi.org/10.1016/j.ecss.2007.01.022

Hossain, M.M. (1971). The commercial fishes of the Bay of Bengal (survey for the development of fisheries, East Pakistan, Chittagong). UNDP Project publication. No. 1 PAK 22:16.

ICMSF (International Commission of Microbiological Specification for Food), Microorganisms in Food 2. Sampling for Microbiological Analysis: Principles and Specific Applications, University of Toronto Press, Toronto, Canada, 2nd edition, 1986.

Kamal, A.H.M. and Khan, M.A.A.(2009). Coastal and estuarine resources of Bangladesh: management and conservation issues. Maejo International Journal of Science and Technology, 3(2): 313-342.

Kolawole, M.O., Ajayi, T.K., Olayemi, B.A. and Okoh, I.A. (2011).
Assessment of water quality in Asa river (Nigeria) and its indigenous Clarias gariepinus Fish. International Journal of Environmental Research and Public Health, 8(11): 433252, https://doi.org/10.3390/ijerph8114332

Latha, N. and Mohan, M.R. (2013). The Bacterial Microflora in the Fish Organs-A Public Health Aspect. Indian Journal of Advances in Chemical Science, 1: 139-143.

McLellan, S.L. and Salmore, A.K. (2003). Evidence for localized bacterial loading as the cause of chronic beach closings in a freshwater marina. Water Research, 37: 2700-2708, https://doi.org/10.1016/S0043-1354(03)00068-X

Odoli, C.O. (2006). The effect of temperature abuse at the beginning of storage on the quality and shelf life of fresh water arctic charr (Salvelinus alpinus). Fisheries Training Programme, pp. 1-46.

Rajkumar, B. and Sharma, G.D. (2013). Seasonal bacteriological analysis of Barak River, Assam, India. Applied Water Science, 3:625-630, https://doi.org/10.1007/s13201-013-0120-3

Rashed-Un-Nabi M., Al-Mamun M.A., Ullah M.H. and Mustafa M.G. (2011). Temporal and spatial distribution of fish and shrimp assemblage in the Bakkhali river estuary of Bangladesh in relation to some water quality parameters. Marine Biology Research, 7(5): 436-452, https://doi.org/10.1080/17451000.2010.527988

Santos, H.F., Carmo, F.L., Paes, J.E., Rosado, A.S., Peixoto, R.S. (2011). Bioremediation of mangroves impacted by petroleum. Water Air Soil Pollution, 216(1-4): 329-350, https://doi.org/10.1007/s11270-010-0536-4

Sichewo, P.R., Gono, R.K., Muzondiwa, J. and Mungwadzi, W. (2014). Isolation and identification of pathogenic bacteria in edible fish: A case study of rural aquaculture projects feeding livestock manure to fish in Zimbabwe. International Journal of Current Microbiology and Applied Sciences, 3(11): 897-904.

Siddique, M.A.M., Abu Hena, M.K. and Aktar, M.(2012). Trace metal concentrations in salt marsh sediments from Bakkhali River estuary, Bangladesh. International Journal of Environmental Studies, 22(3-4): 254-259, https://doi.org/10.1080/21658005.2012.735842

Sujatha, K., Senthilkumar, P., Sangeeta, S. and Gopalakrishnan, M.D. (2011). Isolation of human pathogenic bacteria in two edible fishes, Priacanthus hamrur and Megalaspis cordyla at Royapuram waters of Chennai, India. Indian Journal of Science and Technology, 4(5): 539-541.

Zambuchini, B., Fiorini, D., Verdenelli, M.C., Orpianesi, C. and Ballini, R. (2008). Inhibition of microbiological activity during sole (Solea solea L.) chilled storage by applying ellagic and ascorbic acids. Food Science and Technology, 41: 1733-1741, https://doi.org/10.1016/j.lwt.2007.11.004 